\title{
Views of Teacher-Trainees on Clothing and Textiles Education in two Teacher Education Universities in Ghana
}

\author{
Phyllis Forster ${ }^{1, *}$, Rosemary Quarcoo ${ }^{1}$, Elizabeth Lani Ashong ${ }^{1} \&$ Victoria Ghanney $^{1}$ \\ ${ }^{1}$ Department of Home Economics Education, University of Education,Winneba, P.O. Box 25, Winneba, Ghana \\ ${ }^{*}$ Correspondence: Department of Home Economics Education, University of Education,Winneba, P.O. Box 25, \\ Winneba, Ghana. E-mail: phyllis_forster@yahoo.com
}

Received: September 16, 2016

Accepted: October 4, 2016 Online Published: December 29, 2016

doi:10.5430/wje.v7n1p1

URL: http://dx.doi.org/10.5430/wje.v7n1p1

\begin{abstract}
The study explored the views of teacher-trainees on Clothing and Textiles (C\&T) education in two teacher education universities in Ghana. The objectives were to find out whether pre-tertiary Sewing/C\&T lessons provided them with small-scale business skills, and foundation for higher education, they could teach Sewing/C\&T competently on internship, identify their sources of motivation, and elicit their suggestions to improve on the subject. Data collected revealed that one-tenth and two-thirds acquired small-scale business skills from their lessons at basic and secondary levels respectively. About $71 \%$ indicated they taught the subject competently on internship and career intention was their main motivating factor for the subject. For improvement, there is need to provide adequate modern facilities and competent teachers with current ideas in content and pedagogy, and good teacher relationship with students and industry. Other suggestions were, students should remain focused and attract others to the subject through their dressing. Feed-back from the teacher trainees indicates that Sewing/C\&T education in Ghana provides occupational skills and foundation for further studies.
\end{abstract}

Keywords: trainee-teachers; internship; clothing and textiles; home economics; teacher education; interns

\section{Introduction}

Societies transform individuals to become independent citizens who can make meaningful contributions towards social development through education, defined by Encyclopedia Americana (2005) as any process by which an individual gains knowledge or insight or develops attitude or skills. The functionalist view of education tends to focus on the positive contributions education makes to the maintenance of the social system. Emile Durkheim, a French sociologist, saw the major function of education as the transmission of society's norms and values (Lukes, 1985). According to Durkheim (Lukes), education is the medium through which common standards and values are set to ensure solidarity and unity of thought in society. In their contributions to what education is all about, Merton described it as training given in schools with common curriculum to prepare people for the world of work and Parsons added that after primary socialisation within the family, the school takes over as the focal socialising agency and acts as a bridge between the family and society to prepare children for their adult roles (http://agnihotrieducation.blogspot.com/2008/09/functionalist-theories-of-education.html). Like Parsons, Davis and Moore, cited at the same website, saw education as a means of role allocation, where learners are trained for different roles and levels, but linked the education system more directly with the system of social stratification, which sifts, sorts and grades individuals according to their talents and abilities.

According to Farrant (2004), education may be obtained through formal, informal, or non-formal systems and their combinations. Farrant, and two functionalists, namely, Davis and Moore (http://agnihotrieducation.blogspot.com/2008/09/functionalist-theories-of-education.html) explained that formal education is given through the school system and ends with the award of certificate; non-formal education entails organised teaching and learning activities outside the school system that is aimed at meeting specific learning needs of particular groups of people in the community with planned curriculum, and may end with the award of certificates, just 
like formal education; while informal education entails sub-conscious teaching and learning, has undefined location, and is not associated with the award of certificates. In Ghana, the most popular form of education is the formal system offered in schools and colleges. School education is compulsory for all children in Ghana, aged 4 to $15 y$ years (MOE, 1996) under the Free Compulsory Universal Basic Education (FCUBE) policy. Thus after primary socialisation by the family, all children are brought together in schools and taught social values and goals, and trained for their adult roles in the society with common curriculum in the interest of social development, as Merton indicated (http://agnihotrieducation.blogspot.com/2008/09/functionalist-theories-of-education.html).

Durkheim believed that it is important for individuals to learn to co-operate with those who are neither their kin nor their friends and the school provides a context where these skills can be learned. He found the school to be a miniature society, and a model of the social system which every child has to go through. In school, the child interacts with other members of the school community in terms of a fixed set of rules. The experience prepares him or her to interact with members of society as a whole in terms of society's rules according to Parsons (http://agnihotrieducation.blogspot.com/2008/09/functionalist-theories-of-education.html).

The ultimate goal of schools therefore is to transform students by providing knowledge and skills, and by building character and instilling virtue (Sergiovanni, 1991). It is the duty of the school to ensure that all students, regardless of their social, economic and intellectual statuses, learn and become useful and productive members of society. Sergiovanni's statement appears to blend the convictions of Durkheim, Parsons, Davis and Moore, and Merton (http://agnihotrieducation.blogspot.com/2008/09/functionalist-theories-of-education.html). Schools create a common platform for the training of members of the society to prepare them for responsible adult life and enable them make positive contributions towards development. Consequently, a major objective of the current Ghanaian educational system which is predominantly formal, is to equip individuals with the right knowledge, skills and attitude to enable them contribute meaningfully towards national development goals of poverty alleviation and wealth creation (GES, 2008).

Education has always embraced some vocational elements and aims (MOE, 2002). According to Amedome and Fiagbe (2013), Technical and Vocational Education and Training (TVET) play a vital role in a society's economic growth and social development. Programmes in TVET include competency-based applied learning which contributes to an individual's academic knowledge, higher-ordered reasoning, problem solving skills and occupation-specific skills, necessary for economic independence.

As in the cases of the 1987 and 1992 educational reforms, the 2007 educational reform of Ghana, placed much emphasis on TVET education in order to provide the youth with employable skills and reduce unemployment. One of the programmes under TVET in Ghana is Home Economics, which is studied at all levels of education. Home Economics focuses on theory and practice in schools, and may be oriented as an applied academic programme, a product or technology-producing course, a career education, and independent-living skills which contribute to the development of self-reliant attitudes and abilities (International Federation of Home Economics [IFHE], 2008). Smith and de Zwart (2010) stressed that Home Economics is the only programme which focuses on everyday life and meets basic needs of life. Skills and knowledge developed in Home Economics are useful to learners not only in their personal and family lives but also in securing and holding career opportunities (IFHE, 2008).

$\mathrm{C} \& \mathrm{~T}$ is one of the subjects studied in Home Economics at all the levels of education (basic, secondary and tertiary) in Ghana . At the basic level it falls under Basic Design and Technology (BDT) which combines principles and processes in various aspects of Pre-technical Skills, Home Economics and Visual Arts (GES, 2007). The core skills components studied in the first term at Junior High School (JHS) form one, combine the three areas of BDT, while for the optional skills, learners are expected to study one out of the three skill areas (Pre-technical skills, Home Economics, Visual Arts) for the rest of the JHS period. The Home Economics option comprises Catering and Sewing, and learners are expected to study these fundamentals of Home Economics before progressing to the secondary level, where they can opt for either Clothing and Textiles or Food and Nutrition (F\&N). The Sewing/C\&T teacher is expected to guide students with the competencies required for learning the subject from the basic to the tertiary level of education. At the basic and secondary levels, this subject provides foundation for further studies at the tertiary level leading to several high level careers as well as different levels of occupational skills.

Arubayi (2004) pointed out that C\&T is developed around six central themes. These include the study of fabrics, garment construction, clothing maintenance, consumer education, decorative processes and wardrobe planning, which can all lead to acquisition of skills for jobs in the society. Careers in C\&T cover a broad range of occupations from fabric manufacturing, clothing design, to the selection, sale, use and care of finished goods. Such an important subject needs attention for client appeal in schools in order to increase enrolment and employment rate in the clothing 
industry. However, studies by Tashie (2016) and Ameleke (2015) show that very few students opt for the subject and few teachers trained to teach both $C \& T$, and F\&N teach Sewing/C\&T at the pre-tertiary levels of education in Ghana. In 2006, the UNESCO Institute of Statistics (UIS) commissioned a study to assess the extent of current data knowledge about global provision of TVET in thirty countries including Ghana. The findings also showed that TVET education is portrayed as inferior to general education (Oketch, 2007; UNESCO- UNEVOC, 2006).

According to Maduaka (1997), many lecturers and students perceive C\&T as a very difficult area in Home Economics. Obrifor (1993) and Aiyede (1995) respectively found that 55\% and 70\% of Home Economics teachers preferred to teach F\&N to teaching C\&T. A subject which offers students opportunity to acquire occupational skills should not be allowed to fade out of the educational system, especially in a developing country where the need to mobilize all resources for employment and revenue generation is critical.

In Italy, an important sub-sector in the manufacturing industry is C\&T, which boasts of the world's best known fashion designer labels, such as Valentino, Armani, Versace, Gianfranco Ferré and Krizia. C\&T manufacturing is now Italy's third largest business after engineering and construction. Almost one million workers are employed in this sector. Italy is a leading exporter of clothes and shoes in the world with most producers operating on small or medium-scale (Italian Republic-Country overview, 2015). Everybody needs a variety of clothing for daily use and wherever there are human beings textiles products are used in one way or the other. Clothing and textiles products will therefore be always needed and will continue to create jobs for its learners. If C\&T education is taken seriously and industries are well supported by the government, the sector is capable of enhancing revenue generation in Ghana just like in Italy.

For C\&T education to be effective, teacher quality should be good, the right infrastructure and the teaching-learning materials should also be available and adequate. According to Asare and Nti (2014), in an era where quality education is a concern for education-focused international organizations and dominates national debates, teacher quality must equally be a priority. To these authors the central role of the teacher requires that teacher education be of the highest quality toward achieving any educational agenda. Quality teacher education is crucial for effective education outcomes. The United States of America's National Council on Teacher Quality's (NCTQ) review of university-based teacher preparation programmes concluded that a vast majority of such programmes were inadequately preparing the nation's teachers (Fuller, 2013). In Ghana, the major objective of the Tertiary Education Reforms was to expand access, improve quality teaching and learning and provide the much-needed infrastructural base for accelerated technical manpower delivery for sustainable economic development (www.modernghana.com/GhanaHome/ghana/ghana_education.asp?). The National Teaching Council co-ordinates and regulates teacher education programmes in the tertiary institutions in Ghana and it recognises the importance of continuous teacher development to upgrade and update the competences and skills of serving teachers.

The fact is most professionals, including teachers after their academic training, experience shock when the theory and technical skills they acquired during their academic preparation prove to be ineffective when confronted with problems of practice. According to Kowalski (2012), their bewilderment stems from a misunderstanding of theory and limited insights about the effects of contextual variables on the consistency of applying theory. Teachers are expected to be able to structure their content and pedagogy to suit the cultural environment of their learners since the environment in which they acquire skills for teaching C\&T may be completely different from that of their learners. A teacher who is not able to contextualize content and pedagogy may simply avoid teaching the subject or not teach it well. Crucial and central to C\&T education is therefore the teacher. According to Adegoke (2003), education is a condition for development and the teacher ultimately defines its reality because it is the teacher who develops human resource. Asare (2009) added that a very important element in education is the interactions that go on between the teacher and the learner. He explained that through such interactive processes, education quality is achieved. Good teacher-learner relationship facilitates learning, while poor teacher-learner relationship retards the learning process. The Republic of Ghana Report on the Development of Education in Ghana (GES, 2008) listed friendly and cordial teacher-pupil relationship, participatory and interactive teaching-learning methods, and learner-centred teaching with extensive individual attention as issues of importance to success in education. Asare (2010) also observed that the real threat to learning is how teaching is done and suggested that teachers must be taught to engage learners in such a way that would make the learners own and make sense of activities to promote learning.

Quality is at the heart of all education systems and the quest to ensure that students achieve decent learning outcomes and acquire values and skills that help them play a positive role in their societies is an issue on the policy agenda of nearly every country (Sifuna et al., 2010). Ghana has over the years made efforts to train and develop teachers to form the bedrock of training the manpower needs of the country. The Presidential Committee on Education in Ghana (2002) 
recommended a critical review and approach to making teacher education relevant to the development of the country. Reiterating what teacher education must encapsulate, Adegoke (2003) and Benneh (2006) indicated that the mission of Ghana's teacher education is to provide a comprehensive teacher education programme through pre-service and in-service training that would produce competent, committed, and dedicated teachers to improve the quality of teaching and learning. The pre-service training goes on alright but scarcely does in-service training for teachers take place in Ghana.

One major tool with which the teacher operates is the school curriculum, a tool which sets standards of knowledge, skills and attitudes and their modes and conditions for transmission, assessment and grading. Finch and Crunkilton (1999) stated that curriculum needs to be evaluated often in order to adapt it to meet the current trends in society. They explained that a static curriculum is a dying curriculum and a curriculum which adequately addresses the needs of learners is likely to enjoy high patronage. The education service in Ghana therefore continually reviews the school curricula for it to be current (GES, 1987; 2007; 2010).

\section{Statement of the Problem}

The current educational curriculum of Ghana has been structured to reflect the national development goals of poverty alleviation and wealth creation. Hence, it equips learners with employable skills at all the three levels of education (basic, secondary and tertiary), provides foundation for further studies and prepare the learners for career progression. Post-internship teacher-trainees in the two teacher education universities in Ghana have all had basic and secondary school education, studied C\&T in the teacher education university for six semesters to prepare them to teach at the pre-tertiary levels, and have had field experience in teaching Sewing/C\&T at JHS and SHS across the country on internship. Some teacher-trainees in the two institutions have often complained about lack of interest in the subject, and their inabilities to practice skills learnt in C\&T lessons and teach the subject competently on internship but their views on $C \& T$ education have never been investigated.

TVET education is expected to equip learners with marketable skills and in the case of teacher- trainees, enable them to teach TVET subjects competently. It therefore becomes necessary to investigate the teacher-trainees concerns and develop strategies to address them. Their awareness, experiences and views on the state of affairs with regard to Sewing/C\&T education, first as students and secondly as intern-teachers, were important in identifying drawbacks and repackaging content and pedagogy where necessary in teacher-education universities, to enable them meet the demands of a Sewing/ C\&T teacher at the pre-tertiary levels of education. It is in this vein that as C\&T lecturers in a teacher education university, we undertook this study to have access to the views of our trainees who have been both students and intern teachers of Sewing/C\&T education in Ghana. The aim of the current study therefore was to use people who were directly involved with the learning and teaching of C\&T to evaluate the usefulness of the subject content to learners at the three levels of education and solicit their suggestions for improvement of C\&T education in Ghana.

Objectives of the study were therefore to find out whether the teacher-trainees found knowledge and skills acquired in Sewing/C\&T lessons at the pre-tertiary levels of education useful in small scale businesses; lessons learnt in Sewing/C\&T at lower levels of education served as foundation at the higher levels; they were able to teach the subject well on internship, identify their main sources of motivation for opting for the subject; and elicit their suggestions for improvement in Sewing/C\&T education in Ghana.

Two null hypotheses were tested:

1. $\mathrm{H}_{0}$ : There is no significant relationship between adequacy of teaching-learning facilities and students' interest in Sewing at the basic school level.

2. $\mathrm{H}_{0}$ : There is no significant relationship between adequacy of teaching-learning facilities and students' interest in $\mathrm{C} \& \mathrm{~T}$ at the secondary school level.

\section{Methods}

The target population for this study was teacher-trainees who offered C\&T in the $8^{\text {th }}$ semester of the $2013 / 2014$ academic year at the two public teacher education Universities in Ghana. The census method was employed to select 140 teacher-trainees (31 and 109) in the two institutions. A validated questionnaire with 0.78 reliability coefficient was used to collect the data. Items which sought the teacher-trainees' views on issues were constructed in a 5-point Likert scale with positive scores ranging from strongly agree/very adequate (5-points), agree/adequate (4-points), 
undecided/not sure (3-points), disagree/barely adequate (2-points) to strongly disagree/ inadequate (1-point). Open-ended questions were also used to solicit answers on their sources of motivation for selecting the subject and suggestions for improvement in C\&T education in Ghana.

The data collected also covered the teacher-trainees' opinions about adequacy of equipment in their pre-tertiary schools' Sewing/ C\&T laboratories, the usefulness of knowledge and skills they acquired in Sewing/ C\&T lessons at the pre-tertiary levels in small-scale business, their ability to teach the subject competently as intern-teachers, sources of motivation for learning the subject, and suggestions for improvement of the subject at various levels of education in Ghana. The collected data were analyzed using SPSS to generate frequency and percentage responses while Pearson's R, which is a measure of the degree of correlation between two linear variables, was used to test the hypotheses at 0.01 significance (2-tailed) level.

\section{Results and Discussion}

\subsection{Sex of the Teacher-Trainees}

Only $7.9 \%$ of the trainee-teachers were male, with the rest being female. This agrees with the observation of other researchers (Forster, 2014; Arubayi, 2006; Anyakoha, 1992) that Home Economics is generally viewed as the domain of females. Kuofi (2015) explained that though there is a male dominance in the fashion industry the males prefer to learn garment production through apprenticeship training to avoid being mocked by their peers for offering a "female subject" in school.

\subsection{Views of the Teacher-Trainees on Their Sewing Education at the Basic School Level}

On participation in Sewing lessons, teacher-trainees who offered Sewing in basic school was only $36.4 \%, 57.1 \%$ did not, and $6.5 \%$ did not respond to the question. All the trainees were expected to have studied Sewing at the basic level because it is part of Home Economics education, which is compulsory in JHS 1 in all Ghanaian schools (GES, 2007). The high percentage of teacher-trainees who did not study Sewing agrees with Tashie (2016) and Ameleke (2015) that few students study the subject in basic schools. The current education system in Ghana recognises the fact that JHS education provides opportunity for students to discover their interest, abilities, aptitudes and other potentials, and acquire basic knowledge and skills to enable them prepare adequately for further academic work and acquisition of technical/vocational skills at the SHS level. Hence, all students are given the opportunity to study Home Economics which has Sewing as one of its two components at the basic level (GES, 2007). This enables those good in the subject to realize their potentials and pursue further studies in C\&T at SHS. Davis and Moore cited at $\mathrm{http}: / /$ agnihotrieducation.blogspot.com/2008/09/functionalist-theories-of-education.html, saw education as a means of role allocation where learners are trained for different roles and levels. Clothing needs of society have to be met and it is the responsibility of the education system to train the youth for that purpose. Consequently, the Republic of Ghana report (GES, 2008) states that pre-tertiary TVET shall be provided in all basic and secondary schools, and supervision and monitoring should be undertaken by the district Education directorates to ensure that laid down policies are adhered to. Thus all the trainees would have studied Sewing at JHS if the policy for TVET and supervision were working.

Kowalski (2012) mentioned teaching-learning materials available in the schools and the competencies of teachers as important factors that affect the teaching and learning process. Only $10 \%$ said that the basic schools they attended were adequately equipped with facilities for Sewing lessons. In such situations, teachers are faced with the problem of making the limited resources available work and such decisions may affect the choice of the subject by students and the quality of teaching if the situation is not well managed. Bennell (1999) found that vocational education and training (VET) was largely absent in most government and donor poverty reduction strategies in developing countries. While there is a need to adjust development efforts and build the human assets and capabilities of the poor, vocational education and training has been receiving less and not more attention.

Sewing lessons have both theory and practical components. The practical skills can only be acquired through the use of the right equipment and methods. Hence, facilities have to be appropriate and adequate, and teachers should also be competent enough to enable them teach the right skills. Only 10\% said they developed interest in sewing at the basic level; the knowledge and skills gained in their sewing lessons were adequate for small scale businesses and facilitated the learning of C\&T concepts in SHS. Small scale business skills listed as acquired by the teacher-trainees were crocheting, hand stitching, seaming, mending, tote bag and apron making.

Adequacy of teaching and learning facilities was found to have a weak positive correlation with students' interest in sewing at the basic school level (Pearson's $\mathrm{R}=.261$; $\mathrm{Sig}=.006$ ). This means that as the quality and quantity of 
facilities increase, students' interest in sewing lessons also increases slightly. Being a practical subject, sewing skills need to be demonstrated for students to observe, practice and develop interest for the subject. Theory alone makes Sewing lessons boring and difficult to understand. The latest educational reform (GES, 2007) stated that TVET shall be resourced and promoted as a viable alternative to general education; the curriculum is skill oriented and has been structured to reflect the national development goals of poverty alleviation and wealth creation. The findings do not agree with what is stated in the report. Few of the schools attended by the trainees taught Sewing. Thus, only $10 \%$ said the skills they acquired could be used for small scale business.

\subsection{Views of the Teacher-Trainees on Clothing and Textiles at the Secondary Level of Education}

More of the teacher-trainees studied C\&T in secondary school than the basic school.

Table 1. The Trainee-Teachers Views on C\&T Lessons in SHS $(\mathrm{N}=140)$

\begin{tabular}{lll}
\hline Response & Freq. & Percent \\
\hline Secondary Education in $C \& T(N=140)$ & & \\
\hline Had SHS education & 130 & 92.9 \\
Did not have SHS education & 10 & 7.1 \\
Offered C\&T & 92 & 65.7 \\
Did not offer C\&T & 48 & 34.3 \\
\hline Views on the subject $(N=140)$ & & \\
\hline Teaching and learning facilities were adequate & 88 & 62.9 \\
Found C\&T interesting & 95 & 67.9 \\
Acquired knowledge and skills useful for small scale business & 92 & 65.7 \\
Concepts learnt facilitated learning of C\&T in the university & 88 & 62.9 \\
\hline
\end{tabular}

Teacher-trainees who had SHS education and those who did not have were $92.9 \%$ and $7.1 \%$ respectively (Table1). Those who offered C\&T were $65.7 \%$ and $62.9 \%$ found teaching and learning facilities for the subject moderately adequate in their schools. This is an indication that the state of facilities at the secondary school level is better than the basic level where only $10 \%$ of the schools were adequately resourced for Sewing lessons. Though $65.7 \%$ offered the subject, $67.9 \%$ found it interesting, meaning, some trainees who did not offer the subject also developed interest for it in SHS. Probably, they liked the subject but were discouraged by friends, teachers or parents who find the subject to be suitable for poor academic achievers (Tashie, 2016). All the teacher-trainees who offered the subject (65.7\%) said they acquired knowledge and skills useful for small scale business from their lessons. However, $62.9 \%$ who offered the subject thought the lessons learnt at the secondary level facilitated learning in the university. Acquired business skills listed by the teacher-trainees were hand and domestic machine stitching, seaming, hand embroidery, pattern drafting, fabric selection, use and care and assembling of garments.

The Association for Career and Technical Education (ACTE, 2006) suggested that teachers must engage students in specific career-related learning experiences that equip them to make well-informed decisions about further education, training and employment opportunities and prepare students who may choose to enter the workforce directly after high school with levels of skill and knowledge in particular career areas that will be valued on the job market. The findings of this study suggest that C\&T teachers were generally on course especially at the secondary level of education. Concepts studied by the trainee-teachers in SHS also exposed them to occupation skills of much value to the C\&T industry. At the SHS level, interest was again found to have a weak positive significant relationship with adequacy of facilities for teaching and learning (Pearson's R=.271; Sig. =.004).

A case study in Ghana (Akyeampong, 2002) found that there had been an increase in students taking technical and vocational subjects at SHS level, but it was still not clear how many actually enter the labour market successfully. The 2007 educational reform structured the curriculum to provide knowledge and skills that would be marketable at the end of each of the levels of education, namely, basic, secondary and tertiary, in order to reduce youth unemployment. The teacher-trainees, comments on the usefulness of what they learnt for small scale business indicate that basic school Sewing lessons lay a foundation for secondary school C\&T in addition to preparing learners for the industry, and therefore satisfies the goals of GES (2007) reforms of education.

McWilliams and Kwamena-Poh stated (1975) that the main purpose of education is to produce persons who will be 
useful to society. A subject which is able to make students useful to society, even at the lowest level of education is capable of providing occupational skills to every member of the society who goes through basic education and must therefore be given the desired attention as stated in the GES (2007) policy document to reduce unemployment.

Akyeampong (2002) documented the challenges of skills training provision in terms of the considerable recurrent costs of equipment and materials, professional training of technical teachers, and adequate levels of student enrolment. Teachers cannot teach the subject well without the necessary resources. The results of this study show that the Sewing aspect of Home Economics is generally not given much attention in the basic schools, most probably because the schools were not well resourced with teaching and learning facilities. Hence the knowledge and skills acquired by teachers at the teacher education institutions during training are underutilized. It is possible that only the Catering aspect of Home Economics was taught to prepare students for Basic Certificate Examination (BECE) which includes questions in both Sewing and Catering. In such situations candidates are not likely to obtain good grades and get motivated to pursue further studies in Home Economics subjects at higher levels of education. Davis and Moore said people are educated to enable them play specific roles in the society (http://agnihotrieducation.blogspot.com/2008/09/functionalist-theories-of-education.html). In this study, teachers trained to teach Sewing were probably teaching subjects they had not been trained for or were teaching without the right facilities, and would definitely not be able to deliver lessons effectively with the wrong facilities. Such practices do not make lessons real, effective and interesting to learners.

As recommended by the Presidential Committee on Education (MOE, 2002), a critical review and approach to making teacher education relevant to the development of the country's needs should be considered in Ghana. Consequently, this review was done in 2007 and policies that will ensure effective TVET education were made to guide implementers. The youth have to be trained well to produce good clothing goods but this cannot happen unless the necessary training needs namely, competent teachers and adequate teaching and learning facilities are provided in educational institutions. Regarding knowledge and skill update for competency building in the case of serving teachers, it is clearly indicated in the current educational reform (GES, 2007) that continuous teacher development would be untaken to upgrade and update the competencies and skills of serving teachers and the service conditions for TVET teachers shall be improved to attract and retain qualified and experienced teachers from industry but such actions are not yet visible in the Ghanaian educational system. All students have to be introduced to the subject at the basic level to enable them make informed decision as to whether they would or would not pursue C\&T at higher levels of education as stated in GES (2008) educational development of Ghana report. The report emphasises the provision and free accessibility of adequate text books and other teaching-learning resources to facilitate skills training and acquisition which need to be adhered to for efficiency in education delivery.

Obrifor (1993) and Aiyede (1995) found that Home Economics teachers preferred to teach Foods and Nutrition to Sewing/ C\&T. Ill-trained teachers will find it difficult to teach Sewing / C\&T. Hence, Colleges of Education and teacher education universities, where most basic and secondary school teachers are trained in Ghana have to be well resourced to be able to prepare teacher-trainees well for their job, so that teachers will not neglect the subject in schools. As stated by Farrant (2004), an ignorant teacher cannot enlighten students.

\subsection{Factors Which Motivated the Teacher-Trainees to Opt for C\&T}

Biehler and Snowman (1993) stated that motivation is typically defined as the forces that account for the arousal, selection, direction, and continuation of behaviour. It is the responsibility of the school to create the conditions that will induce and enhance students' motivation to pursue academic goals actively over a long period of time. Many students in SHS in Ghana do not opt for C\&T and the few who desire to choose that option are often discouraged by their friends, parents and teachers, especially if they are academically good (Tashie, 2016). A question on factors which motivated the teacher-trainees to select C\&T in secondary school generated answers in Table 2.

Table 2. Factors Which Motivated the Teacher-Trainees to Study C\&T in Secondary School ( $N=140)$

\begin{tabular}{lll}
\hline Factor & Freq. & Percent. \\
\hline Career intention & 59 & 64.3 \\
Programme package (Home Economics) & 28 & 30.7 \\
Parent's influence & 4 & 4.3 \\
Role model's influence & 1 & 0.7 \\
Total & 92 & 100 \\
\hline
\end{tabular}


From Table 2 career intention (64.3\%), programme package (30.7\%), parent's influence $(4.3 \%)$ and role models influence $(0.7 \%)$ motivated the trainees to opt for C\&T in SHS. Career intension was therefore the main motivator for their choice of the subject at that level. According to some researchers (Oketch 2007; UNESCO-UNEVOC, 2006), TVET education is portrayed as inferior to general education and job creation hence, many students at all levels of education often do not want to opt for vocational and technical subjects in school. Findings in this study have shown that many students are attracted to the subject because of its ability to provide them with careers. Forster (2014) and Anyakoha (1992) listed several carriers in the area of C\&T which learners qualify for after JHS, SHS and university education. Many students, after basic school education may want to start life with low level jobs and develop themselves to higher positions later in life when their economic status improves. Even if students who benefit from Sewing/ C\&T education decide not to engage in related careers they can use the knowledge, skills and attitudes acquired to help themselves and their families select, use and care for their clothing better in order to save money for other needs (Smith \& de Zwart, 2010).

\subsection{The Teacher-Trainees Experiences in C\&T at the Teacher Education University}

How the teacher-trainees felt at the commencement of the course, whether they were satisfied with content and pedagogy, and their ability to teach C\&T competently on internship are presented in Table 3.

Table 3. Experiences of the Trainee-Teachers at the Teacher Education University

\begin{tabular}{|c|c|c|c|}
\hline Responses & & Freq. & Percent \\
\hline \multicolumn{4}{|c|}{ How trainees felt at the beginning: } \\
\hline & Enthusiastic & 96 & 68.6 \\
\hline & Indifference & 19 & 13.6 \\
\hline & Felt forced & 25 & 17.9 \\
\hline Total & & 140 & 100 \\
\hline \multicolumn{4}{|c|}{ Satisfaction with course content and pedagogy: } \\
\hline & Satisfied & 87 & 62.1 \\
\hline & Indifferent & 20 & 14.3 \\
\hline & Not satisfied & 33 & 23.6 \\
\hline Total & & 140 & 100 \\
\hline \multicolumn{4}{|c|}{ Competency as an intern teacher of the subject: } \\
\hline & Competent & 99 & 70.7 \\
\hline & Not sure & 11 & 7.9 \\
\hline & Not competent & 13 & 9.3 \\
\hline & Non response & 17 & 12.1 \\
\hline Total & & 140 & 100 \\
\hline
\end{tabular}

Most of the teacher-trainees (68.6\%) were very enthusiastic in studying the C\&T course at the university. Only $13.6 \%$ felt indifferent and $17.9 \%$ did not like it. Those who did not like the course explained that they accepted to study C\&T because it was part of the programme available to them (Home Economics Education) at the university. Interest counts a lot in education and therefore where interest is low teachers have to device strategies to motivate students.

Regarding their satisfaction with content and pedagogy of the subject, $62.1 \%$ answered in the affirmative, $14.3 \%$ and $23.6 \%$ indicated they were either not sure or not satisfied. A high percentage of the teacher-trainees $(70.7 \%)$ stated that they could teach C\&T competently as interns, $7.9 \%$ were not sure whether they taught well or not, while $9.3 \%$ said they could not teach it well, and the rest (12.1\%) did not answer the question. Though the impression created here is that more students were able to fulfil their occupational demands, it is worrying to note that a significant percentage $(29.3 \%$ ) was not sure about their ability to teach the subject competently as intern-teachers while $12.1 \%$ ignored the question.

Kowalski (2012) draws attention to the fact that most professionals experience shock when what they learnt in school proves to be ineffective when confronted with problems in practice. He explained that this situation stems from a misunderstanding of theory and limited insights about the effects of contextual variables on the consistency of 
applying theory. It is possible that the $29.3 \%$ who were not confident about their ability to teach C\&T well as interns, had problems contextualizing what they learnt in their training to fit their students, resources, societal expectations and for organizational conditions during their internship. These teacher-trainees might either refuse to teach or not teach the subject well after graduation unless some intervention programme was designed to help them get over their incompetence. The Republic of Ghana Report on the Development of Education (GES, 2008) stated that teachers as facilitators of learning need to be taught to have a clear sense of diverse needs of learners so that they can plan lessons and assess learning outcomes with appropriate assessment approaches. Parsons saw the educational system as an important mechanism for the selection of individuals for their future role in society(http://agnihotrieducation.blogspot.com/2008/09/functionalist-theories-of education.html). Thus schools, by teaching, testing and evaluating students, match their talents, skills and capacity to the jobs for which they are best suited. In order to help teacher-trainees who could not teach the subject competently, lecturers may have to re-package their course content and modify pedagogy to improve learning and skill acquisition in the course to make them successful in their career.

The teacher-trainees listed relevant concepts they were not taught at any of the three levels of education as: exhibition, modelling and fashion show, freehand cutting, millinery, accessories, entrepreneurship, tailoring, quality control, sketching, modelling, the use of the electronic and industrial sewing machine, fibre and fabric identification, and designing which they need to study to enable them teach well. Probably, teachers/lecturers avoided those concepts because of facility inadequacy or they were deficient in knowledge and skills. The 2007 educational report of Ghana emphasised community participation, ownership and management of the TVET programme and a link of education to the world of work (GES, 2008). Institutions which offer TVET have to link with C\&T industries in the community and ask for their support, since the training given to teacher- trainees and in the ultimate, their students prepares them to work in the industry.

Darling-Hammond (2006) pointed out that the critical factor or the most significant indicator of student success is an excellent teacher; one who facilitates learning in the classroom. If teacher education programmes leave new teachers poorly prepared, they will actually increase their inefficiency, attrition rate and reduce client appeal for the subject. Teachers have to be trained well to enable them teach well.

The assumption that the quality of the teacher is directly linked to the quality of instruction and student learning has been embedded in nearly every major school reform strategy. Stein and Gewirtzman (2003) argued that if high quality teachers are so important, it must be determined where they come from and whose responsibility it is to develop them. Their argument suggests that the teacher-trainees were likely to teach competently if they were well trained in their teacher education institutions because, well trained teachers are more likely to be competent teachers than ill-trained teachers. However, no matter how well a teacher is trained, with time and the changes that come with it, the teacher's competency runs down, and therefore has to be redeveloped to match with changes of the time. Teachers' inability to teach competently cannot be blamed on the training they received in their training institutions alone. As suggested by Benneh (2006) and Adegoke (2003), through in-service training teachers on the job may be helped to become competent, committed and dedicated to improve the quality of teaching and learning. Hence, in order to sustain teacher competency, teacher education should be continuous throughout a teacher's service period as suggested by Benneh and Adegoke. Continuous education is one of the policies of GES (2007) to ensure teacher competency.

\subsection{Suggestions for Improvement in Sewing/C\&T in Ghana}

Following their experiences at the various levels of education the teacher-trainees made suggestions to the government, teachers/lecturers and students for improvement in C\&T education at the various levels of education in Ghana.

\subsubsection{Government}

The teacher-trainees suggested that government should supply C\&T laboratories in all schools with adequate modern equipment for practical lessons; supply relevant text books and modern teaching and learning materials, absorb fees for practical lessons, offer scholarship to students who excel in the subject to attract other students, sponsor lecturers to further their education abroad to enable them introduce current ideas into their lessons since the subject is very dynamic, build production units in all tertiary institutions to provide industrial experience to learners, award sewing contracts such as the sewing of basic school uniforms to tertiary institutions for income generation and the development of the institutions' C\&T units, build C\&T factories in the regions to create avenues for industrial training for students and employment after school, support C\&T industries to sustain their operations in order to attract the youth to that sector of the economy, and encourage more students to opt for the subject in school, ensure 
that only teachers who have specialized in the subject teach it. The trainees totally ignored the support of their parents, and community participation, ownership and management responsibilities in the 2007 policy document (GES, 2007).

\subsubsection{Teachers/Lecturers}

Asare and Nti (2014) stated that the central role of the teacher requires that teacher education must be of the highest quality toward achieving any educational agenda. Suggestions were made by the trainees to help C\&T educators to improve content and pedagogy at the three levels of education. In agreement with Asare and Nti (2014), the teacher-trainees suggested that universities, colleges of education, Teacher Education Division (TED) of the GES, and all bodies involved in teacher education in Ghana must join forces to modify content and pedagogy for the subject in order to promote critical thinking skills in teachers.

The teacher-trainees again suggested that $C \& T$ educators should ensure that; their schools are well equipped with adequate modern facilities and text books for teaching-learning, they use appropriate teaching-learning materials to make practical lessons interesting and effective, they take both theory and practical lessons seriously, allow students to select and design their own projects, guide and supervise students' work well during practical lessons, they commend students on their effort to motivate them, should be patient with students who are not able to meet their performance expectations in order not to discourage them, display all project works and allow students to comment and make suggestions for improvement where necessary, show enthusiasm in the subject to inspire and encourage students to work hard, organize exhibitions often to motivate students, stop underrating local tailors and dressmakers and rather ask for their support as resource persons when it becomes necessary, take students out for field trips to textiles and garments' industries to motivate them, invite people who have made it through C\&T education to give talks on benefits of the subject, make C\&T compulsory for all Home Economics students in teacher education institutions so that they do not neglect Sewing in the schools, organise education days to inform students, staff and parents about career opportunities in C\&T; they upgrade themselves to make their lessons relevant since the subject is very dynamic, and refrain from teaching the subject if they have not attended any capacity building programmes since the development of the current curriculum. The student teachers had more suggestions to make to the teachers than to the government and students, which agrees with Fleck (1974) that a teacher's contribution to the success of education is enormous.

Durkheim (Lukes, 1972) indicated that teachers inculcate the ideals and knowledge of society in their students. Thus changes in both the method and content of teaching necessarily embody many important and substantial changes in the greater culture (Lukes, 1972). The quality of education cannot be discussed without mentioning teacher preparation. The trainee-teachers' suggestions for teachers at the three levels of education agree with Alliance for Excellent Education (AEE, 2010) suggestion that teacher preparation programmes for both academic and career preparation must include unique training objectives beyond basic pedagogical and subject area knowledge, coordinate industry specific experiences for students through career day talks by inviting guest speakers from the community and taking students on field-trip, develop innovative approaches to engaging students, and expand their own knowledge so that they remain current in their chosen fields. The trainees' suggestions give a hint that they were not given much space to develop their unique creative abilities in the subject; some teachers/lecturers were deficient in content and pedagogy; and related poorly with students and experts in the C\&T industry.

According to Lynch (1998), traditional teacher training programmes are not effective for creative teacher education because the traditional programmes assume prior knowledge or experience in the education field. Teachers are expected to apply their knowledge and skills in content and pedagogy to teach what the curriculum has designed in which ever context they find themselves. According to the trainee-teachers, teachers who do not upgrade themselves to be abreast with reviewed curriculum should not teach the subject. The student-teachers added that teachers/lecturers should be sponsored to train abroad for more global perspectives and continuous teacher education programmes must be organized regularly to update teachers' knowledge and skills in Sewing/C\&T.

Bruening et al. (2001) found the existing teacher education programmes to be too traditional in nature. As stated by some teacher-trainees, many C\&T teachers may not invite experts such as tailors and dressmakers who are skilled in garment construction, and older women skilled in crocheting and hand embroidery in their communities as resource persons to handle related topics in their class due to inferiority complex. Interactions with experts in the C\&T industries will help to make theory lessons learnt in abstract real and interesting to students.

Brennen stated that learners are motivated to learn when they perceive that teachers care about them (http://www.soencouragement.org/enhancing-students-motivation.htm) and GES (2007) policy on TVET education also stated that teacher-learner relationship should be friendly and cordial. The importance of cordial relationship 
between educators and learners in C\&T education cannot be overemphasised.

\subsubsection{Students}

With regard to what students may do to improve C\&T education in Ghana, the teacher-trainees suggested that C\&T students should avoid self pity and rather be inspired by role models in C\&T careers, remain focused, be creative in their choice of projects, obey teachers'/lecturers' instructions, express their acquired skills, knowledge and attitudes through their dressing to motivate others and attract respect for the subject.

At all the three levels of education and especially in secondary schools, students who opt for C\&T are regarded as low academic achievers (Forster, 2014; Ameleke, 2015) just like all other students who opt for TVET subjects (Oketch, 2007; UNESCO, 2006). Hence, students who find themselves in the C\&T class remain in self pity. The trainees' suggestions may help to boost the morale of students who offer the subject.

\section{Conclusion and Recommendations}

Findings in this study have provided insight into the experiences and opinions of trainee-teachers in teacher education universities in Ghana and elicited their suggestions to help improve pedagogy and content in C\&T in teacher education universities. The findings show that C\&T lessons at all the levels of education in Ghana provide occupational skills and foundation for further studies, in line with objectives of the GES (2007) education reform demands. However, basic schools are generally ill resourced for Sewing lessons, while secondary schools are on the average, well resourced for C\&T lessons. Interest of students in C\&T is also found to have a positive relationship with the adequacy of teaching and learning resources. Hence, for improvement of Sewing/C\&T education in Ghana, the government has to supply adequate modern teaching and learning materials for Sewing/C\&T lessons, and provide quality teachers and lecturers who can teach current content knowledge and skills competently for students to be abreast with changes in the C\&T industry. There is also the need for teachers and lecturers to update their content and pedagogical knowledge and skills and improve their interpersonal relationship with students and experts in the Clothing/Fashion industry, and students to remain focused and obedient to their teachers. The main source of motivation for students' patronage of C\&T was found to be career intention.

Most importantly the GES (2007) education policies on school supervision, provision of teaching/learning resources, continuous education for serving teachers, teacher motivation for TVET teachers, and school-work link should be adhered to in order to improve Sewing/C\&T education in schools.

There is need for teacher education universities to conduct tracer studies of their graduates to identify their challenges and incorporate their findings in pre-service and post-service training programmes for C\&T teachers. They may in collaboration with Ghana Education Service (GES) organise continuous education for teachers in service regularly for incremental improvement in content and pedagogy.

Since teacher-student relationship affects learning outcomes, lecturers/teachers should improve their relationship with students by making their lessons learner centred and providing individual attention. They also have to link up with entrepreneurs to promote school-industry relationship and make it easier for students to learn and access the knowledge and skills of experts in the C\&T industry. Pedagogy also needs to be varied by teachers/lecturers to ensure that both fast and slow learners benefit from C\&T lessons and experiences of entrepreneurs are tapped in schools to assure students of the job relevance of their lessons.

In order to improve student enrolment, career education in C\&T, exhibitions, fashion shows and field trips should be organised by lecturers/teachers at all levels of education to motivate and attract students to the subject.

Finally, lecturers/teachers should link up with the Ghana Home Economics Association and use their platform to network and share ideas among university faculty, industrialists and pre- tertiary teachers to ensure lasting instructional effectiveness of C\&T educators in Ghana.

\section{References}

Adegoke, K. A. (2003). Capacity building of lead teacher training institutions in Sub-Saharan Africa. UNESCO. Retrieved May 16, 2016 from www.unesco.org

Akyeampong, A. (2005). Vocationalisation of secondary education in Ghana. In Lauglo, J. and Maclean, R. (eds.), Vocationalisation of secondary education revisited. UNEVOC/World Bank: Springer. https://doi.org/10.1007/1-4020-3034-7_5 
Alliance for Excellent Education (2010). The Linked Learning Approach: Building the Capacity of Teachers to Prepare Students for College and Careers. Washington, D.C.: Alliance for Excellent Education.

Amedome, S. K. (2013). Challenges facing technical and vocational education in Ghana. International Journal of Scientific \& Technology, 2(6), 253-255.

Ameleke, G. (2015). Teachers' views about the teaching of Clothing and Textiles in Senior High Schools in the southern Volta region, Ghana. Winneba, Ghana: Unpublished dissertation, University of Education, Winneba.

Anyakoha, E. U. (1992). Development and utilization of facilities for Home Economics programme in Nigerian schools. Nsukka: NVA Publication.

Arubayi, D. (2004). A Case Study of Teaching Area Preference of Home Economics Part time . Abraka, Nigeria.: Unpublished B.Ed. Thesis, Delta State University.

Arubayi, D. (2006). Student Enrolment, Academic Staff Quantity and Teachers Students Ratio in Home Economics in Clleges of Education in Nigeria. Journal of Educational Research and Development, 5(1), 118-204.

Asare, K. B. (2009). Education: Training, retraining, and retaining teachers in Ghana (Part 1). Retrieved from htt://www.modernghana.com/news/211101/1/education-training-retraining-and-retaining-teache.html

Asare, K. B. (2010). Teachers' receptivity to curriculum innovations. Ontario Journal of African Educational Research, 1, 81-94.

Asare, K. B., \& Nti, S. K. (2014). Report of the President's committee on education reforms in Ghana. Accra, Ghana: Adwinsa Publications.

Association for Career and Technical Education (2006). Reinventing the American High School for the 21st Century. Alexandria, VA: Author. from http://www.acteonline.org/uploadedFiles/Issues_and_Advocacy/files/ACTEHSReform_Full pdf

Benneh, M. (2006). Particular issues on teacher education and training in Ghana. Dakar, Senegal: UNESCO (TTISSA).

Bennell, P. (nd). Enhancing students' motivation. Retrieved from http://www.soencouragement.org/enhancing-students-motivation.htm 15/10/2016.

Biehler, R. F., \& Snowman, J. (1993). Psychology applied to teaching. Boston: Houghton Mifflin Company.

Brennen, A. M. (nd). Enhancing students' motivation. Retrieved from http://www.soencouragement.org/enhancing-students-motivation.htm 15/10/2016

Bruening, T. H., Scanlon, D. C., Hoover, T. S., Hodes, C., Shao, X., \& Dhital, P., et al. (2001, December). Attributes and characteristics of exemplary, leading, and innovative career and technical education teacher preparation programs. St. Paul, MN: National Research Centre for Career and Technical Education, University of Minnesota.

Darling-Hammond, L. (2006). Powerful teacher education: lessons from exemplary programs. Michigan, USA: Jossey-Bass.

Encyclopaedia Americana (2005). Danbury Conn. Scholastic Library Publishing.

Farrant, J. S. (2004). Principles and Practice of Education. England: Longman Group UK Ltd.

Finch, C. R. \& Crunkilton, J. R. (1999). Curriculum development in vocational and technical education: Planning, content and implementation. Boston: Allyn \& Bacon.

Fleck, H. J. (1974). Towards better teaching of Home Economics. New York: McMillan.

Forster, P. (2014). Clothing and Textiles. Accra: Winmat Publishers Ltd.

Fuller, E. J. (2013). Shaky methods, Shaky motives: A critique of the National Council of Teacher Quality's review of teacher preparation programs. USA: Penn State University.

Functionalist Theories of Education (September 22, 2008). Retrieved 16th May, 2016 from http://agnihotrieducation.blogspot.com/2008/09/functionalist-theories-of-education.html

Ghana Education Service (1987). Ghana's educational system. Accra: Ministry of Education publication.

Ghana Education Service (2007). Ghana's educational system. Accra:Ministry of Education publication.

Ghana Education Service (2008). Educational reforms of Ghana. Accra: Ministry of Education Publication. 
Ghana Education Service (2010). Teaching syllabus for Clothing and Textiles (Senior High School 1-3). Accra: Ministry of Education publication.

International Federation of Home Economics (2008). Home Economics in the 21st Century.Position paper. Retrieved 22 Feb, 2015 from http://www.ifhe.org/

Italian Republic Country Overview (2015). Retrieved, September 8, 2016 frm www.nationencyclopedia.com

Kowalski, E. M. (2012). The infusion approach to teacher development. Journal of Physical Education, Recreation and Dance, 66(4), 49-54. https://doi.org/10.1080/07303084.1995.10608141

Kuofi, T. (2015). Professional background of males in the fashion industry in the CapeCoast metropolis. Capa Coast, Ghana: University of Education, Winneba.

Lukes, S. (1972). Emile Durkheim: His life and work. New York: Harper \& Row.

Lynch, R. L. (1998). Occupational experience as the basis for alternative teacher certification in vocational education. In A. Gamoran, Quality of vocational education (ED 419950). Washington, DC: hhttp://www.ed.gov/pubs/VoEd/Chapter2/Part2.

Maduaka, E. A. (1997). Identification of Problems Perceived by Students in Basic Drafting and Manipulation of Students in Delta State University, Abraka. Journal of Research and Development in Education (JORDE), II(1), 56-62.

McWilliam, H.O.A., \& Kwamena-Poh, M. A. (1975). The development of education in Ghana: An outline. London, England: Longman group.

Ministry of Education (2002). The Educational Reform Programme: Policy Guidelines on Education. Accra: MOE.

Ministry of Education. (1987). Ghana education. Accra, Ghana: Ministry of Education Publication

Ministry of Education. (1992). Ghana education. Accra, Ghana: Ministry of Education Publication

Ministry of Education. (1996). Ghana education. Accra, Ghana: Ministry of Education Publication

Obrifor, A. O. (1993). An investigation into Factors affecting the teaching of Clothing and Textiles in Secondary Schools in Oredo Local Government Area. Unpublished M.Ed Thesis.

Oketch, M. O. (2007). To vocationalise or not to vocationalise? Perspectives on current trends and issues in technical and vocational education and training (TVET) in Africa. International Journal of Educational Development, 27(2007), 220-234. https://doi.org/10.1016/j.ijedudev.2006.07.004

Sifuna, D. N., \& Sawamura, N. (2010). Challenges of quality education in Sub-Saharan African Countries. New York: Nova Science Publishers.

Smith, G., \& deZwart, M. L. (2010). Home Economics: A contextual study of the subject and Home Economics teacher education. The Teacher Inquiry Project.

Stein, S. J., \& Gewirtzman, L. (2003). Principal training on the ground: ensuring highly qualified leadership. Portsmouth, NH: Heinemann.

Tashie, E. (2016). Enrolment of Clothing and Textiles students: A case study of Senior High Schools in the Kwaebibirem district. Unpublished dissertation. University of Education, Winneba, Ghana.

UNESCO-UNEVOC (2006). Participation in formal technical and vocational education programmes worldwide: an initial statistical study. Bonn, Germany: UNESCOUNEVOC International centre for technical and vocational education and training. 